\title{
Sources of organic matter in Changjiang (Yangtze River) bed sediments: Preliminary insights from organic geochemical proxies
}

\author{
Zhongqiao $\mathrm{Li}^{\mathrm{a}}$, Francien Peterse ${ }^{\mathrm{b}, \mathrm{c}}$, Ying $\mathrm{Wu}^{\mathrm{a}, *}$, Hongyan Bao ${ }^{\mathrm{a}}$, Timothy I. Eglinton ${ }^{\mathrm{b}}$, Jing Zhang ${ }^{\mathrm{a}}$ \\ ${ }^{a}$ State Key Laboratory of Estuarine and Coastal Research, East China Normal University, Shanghai 200062, China \\ ${ }^{\mathrm{b}}$ Geological Institute, Department of Earth Sciences, ETH, 8092 Zürich, Switzerland \\ ' Department of Earth Sciences, Utrecht University, 3584 CD Utrecht, The Netherlands
}

\section{A R T I C L E I N F O}

\section{Article history:}

Received 29 September 2014

Received in revised form 1 April 2015

Accepted 2 April 2015

Available online 11 May 2015

\section{Keywords:}

Changjiang

Riverbed sediments

$\delta^{13} \mathrm{C}$

Lignin

GDGTs

\begin{abstract}
A B S T R A C T
Insight into the content and composition of organic carbon (OC) in river systems contributes to our understanding of the global carbon cycle. The Changjiang (Yangtze River) plays a significant role in global carbon and hydrological cycles, as it is an important supplier of sediment, nutrients and OC to the East China Sea. To provide a preliminary insight into the source of OC transported by the Changjiang, we analyzed bulk (grain size, organic carbon content, $\delta^{13} \mathrm{C}$ ), and molecular (lignin phenols, branched and isoprenoid GDGTs) characteristics of organic matter in bed sediments at eight locations along the river. The $\delta^{13} \mathrm{C}$ values and lignin phenol composition indicate that the OC originates from a mixture of primarily soils and plants. Comparison between branched GDGT (br GDGT) distributions in riverbed sediments and those in the different soil types in the drainage basin indicate that the br GDGT signal in the upper reaches is largely derived from soils from the Qinghai-Tibet Plateau. Downstream changes in br GDGT distributions can be linked to subsequent input of local soil material. The observed variation in br GDGT composition along the river implies that a portion of the $\mathrm{OC}$ may be oxidized or replaced by the local input during transit. Although the relationship between $\delta^{13} \mathrm{C}$ and lignin phenol composition indicates that the contribution of phytoplankton is limited, comparison of GDGT ratios (GDGT-0:crenarchaeol, iso GDGTs:br GDGTs, BIT index) for the sediments and surrounding soils indicates that at least part of the iso GDGTs has an aquatic origin. Overall, the downstream evolution of br GDGTs in the Changjiang implies that their use as paleoclimate proxy in downcore applications will likely yield a local, rather than a basin-integrated continental climate record.
\end{abstract}

(c) 2015 Elsevier Ltd. All rights reserved.

\section{Introduction}

Over the last few decades, the importance of the role of rivers in the global carbon cycle has been increasingly appreciated (Hedges, 1992). On a global basis, rivers transport ca. 0.35-0.50 Pg organic carbon (OC) to the oceans per annum (Hedges et al., 1997; Lal, 2003). Rivers form a key connection between the terrestrial and marine carbon cycles, constituting the primary mode of carbon transport from continents to the ocean (Smil, 2007) and are thus key focal points in "source to sink" studies (Blair et al., 2004; Galy et al., 2007; He et al., 2013). Suspended particulate matter (SPM) is the most important carrier of particulate OC from continent to ocean. During the transport of SPM, riverbed sediment may also be important due to hydrodynamic mixing between suspended and bed sediments. Thus, the bed sediment plays a role as

\footnotetext{
* Corresponding author. Tel.: +86 21 62232073; fax: +86 2162546441 .

E-mail address: wuying@sklec.ecnu.edu.cn (Y. Wu).
}

both source and sink of SPM in the river system. The properties and behavior of river-transported OC depend not only on geomorphic and hydrological properties of the basin, but also on the composition and provenance of the material. Hence, studying the sources and characteristics of OC within major river basins contributes to a better understanding of catchment dynamics and its role in the global carbon cycle. Bulk and molecular characteristics are commonly used to determine the composition, sources and the transformation processes of organic matter $(\mathrm{OM})$ in river systems (e.g. Hedges et al., 1986; Wu et al., 2007; Galy et al., 2008a; Ponton et al., 2014). Asian Rivers are thought to be responsible for ca. $40 \%$ of global land-sea C transfer (Galy et al., 2008b; He et al., 2013). Within Asia, the Changjiang (Fig. 1) is one of the major transporters of sediments and thereby influences global geochemical cycles (He et al., 2013). Studies of the characteristics of particulate and dissolved material and their transport in the Changjiang system have indicated that soils are the main source of particulate OC (Wu et al., 2007; Bao et al., 2012b). However, the provenance 


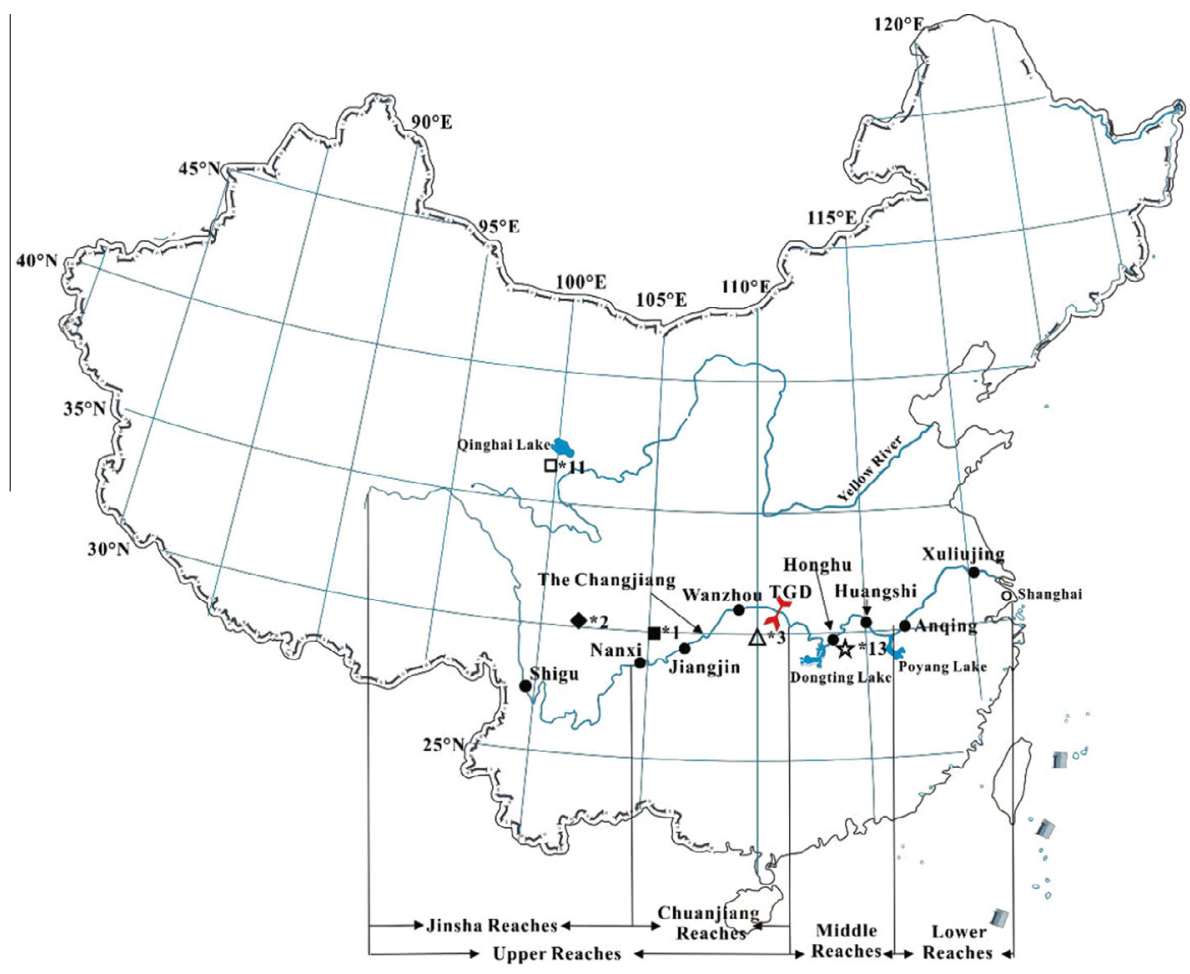

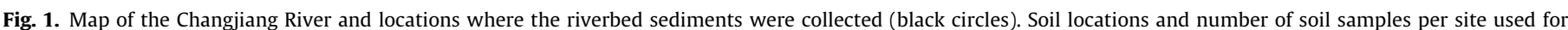

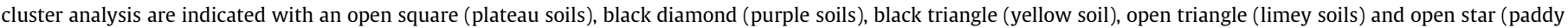

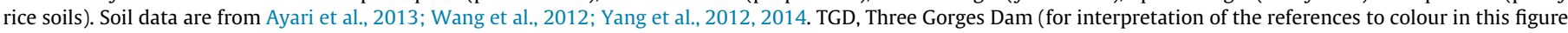
legend, the reader is referred to the web version of the article).

and properties of soil material transported by the river and discharged to the adjacent East China Sea have not been determined. Lignin phenol characteristics of SPM from the middle and lower reaches of the river indicated that the Three Gorges Dam (TGD; Fig. 1) traps particulate OC, modifying the influence of OC flux from the Dongting and Poyang lakes (Yu et al., 2011; Bao et al., 2012b). These observations suggest that the terrigenous $C$ signal may be subject to extensive attenuation and modification along the course of the river.

The stable isotopic composition of $\mathrm{OC}\left(\delta^{13} \mathrm{C}\right)$ is helpful for tracing the OC source in a river system (Raymond and Bauer, 2001). $\delta^{13} \mathrm{C}$ values are generally used to identify vascular plant inputs from $C_{3}$ vs. $C_{4}$ vegetation, or to distinguish between OM of (higher plant) and aquatic origin. With respect to the latter, freshwater phytoplankton biomass tends to have lower $\delta^{13} \mathrm{C}$ values than $\mathrm{OC}$ derived from higher plants and soils (Hamilton and Lewis Jr., 1992). Based on the $\delta^{13} \mathrm{C}$ of SPM and bed sediments in the Ganga-Brahmaputra river system, Galy et al. (2008a) found that the contribution of $\mathrm{C}_{4}$ plants was higher in the delta region than in the plateau region.

Additionally, biomarkers, such as lignin phenols and glycerol dialkyl glycerol tetraethers (GDGTs; Fig. 2), have been widely studied to trace sources of OC in fluvial sediments (Goñi et al., 2000; Walsh et al., 2008; Schouten et al., 2013). Lignin phenols are useful for tracing OM derived from the land surface, as they derive exclusively from the structural tissue of higher plants (Hedges et al., 1986; Yu et al., 2011). Lignin concentration, typically expressed as the total concentration of vanillyl $(\mathrm{V})$, syringyl $(\mathrm{S})$ and cinnamyl (C) phenols normalized to sediment mass $(\Sigma 8)$ or to OC $(\Lambda 8)$, are lower in soil than fresh plants, due to microbial degradation (Hedges et al., 1988). Additionally, information on plant type can be derived from the ratios of syringyl and cinnamyl phenols to vanillyl phenols (S/V and $\mathrm{C} / \mathrm{V}$, respectively). For example, angiosperm plants tend to have a higher S/V ratio (> 0.4) than gymnosperm plants, while woody plants have a lower C/V ratio (ca. 0) than plants with non-woody tissue (Hedges et al., 1986). The GDGTs have recently been introduced as an additional tracer for the input of soil OC to the aquatic environment (Hopmans et al., 2004; Kim et al., 2012). GDGTs are membrane lipids synthesized by archaea and bacteria (Langworthy et al., 1982; De Rosa and Gambacorta, 1988; Damsté et al., 2007) and can be divided into two groups: branched, and isoprenoid GDGTs (br GDGTs and iso GDGTs). The br GDGTs are thought to be produced primarily by anaerobic bacteria and are ubiquitous in soil (Weijers et al., 2007), lake sediments (Blaga et al., 2009; Powers et al., 2010; Pearson et al., 2011), peat (Weijers et al., 2004), and estuarine and ocean margin sediments (Hopmans et al., 2004; Zhu et al., 2011), as well as rivers (Kim et al., 2012; Yang et al., 2013; Zell et al., 2013; De Jonge et al., 2014). It has been reported that the degree of methylation (MBT index) of br GDGTs is related to mean air temperature (MAT) and soil $\mathrm{pH}$ and the degree of cyclisation (CBT index) is related to soil pH (Weijers et al., 2007). Changes in the distribution of br GDGTs throughout a sedimentary archive have consequently been used to reconstruct the MAT and soil $\mathrm{pH}$ in the environment of their producers (Weijers et al., 2007; Peterse et al., 2012; Yang et al., 2014). Iso GDGTs are produced by archaea and are prevalent in the marine environment (Schouten et al., 2013 and references therein), although they have also been detected in peat bogs (Weijers et al., 2004) and soil (Weijers et al., 2006; Wang et al., 2012). In the marine environment, pelagic Thaumarchaeota (previously termed Crenarchaeota) are considered the main source of iso GDGT lipids (Schouten et al., 2013). Given the general predominance of br GDGTs in soils and iso GDGTs in the oceans, their ratio has been proposed as a proxy for determining the relative input of riverine transported soil OM to a marine environment, quantified via the 


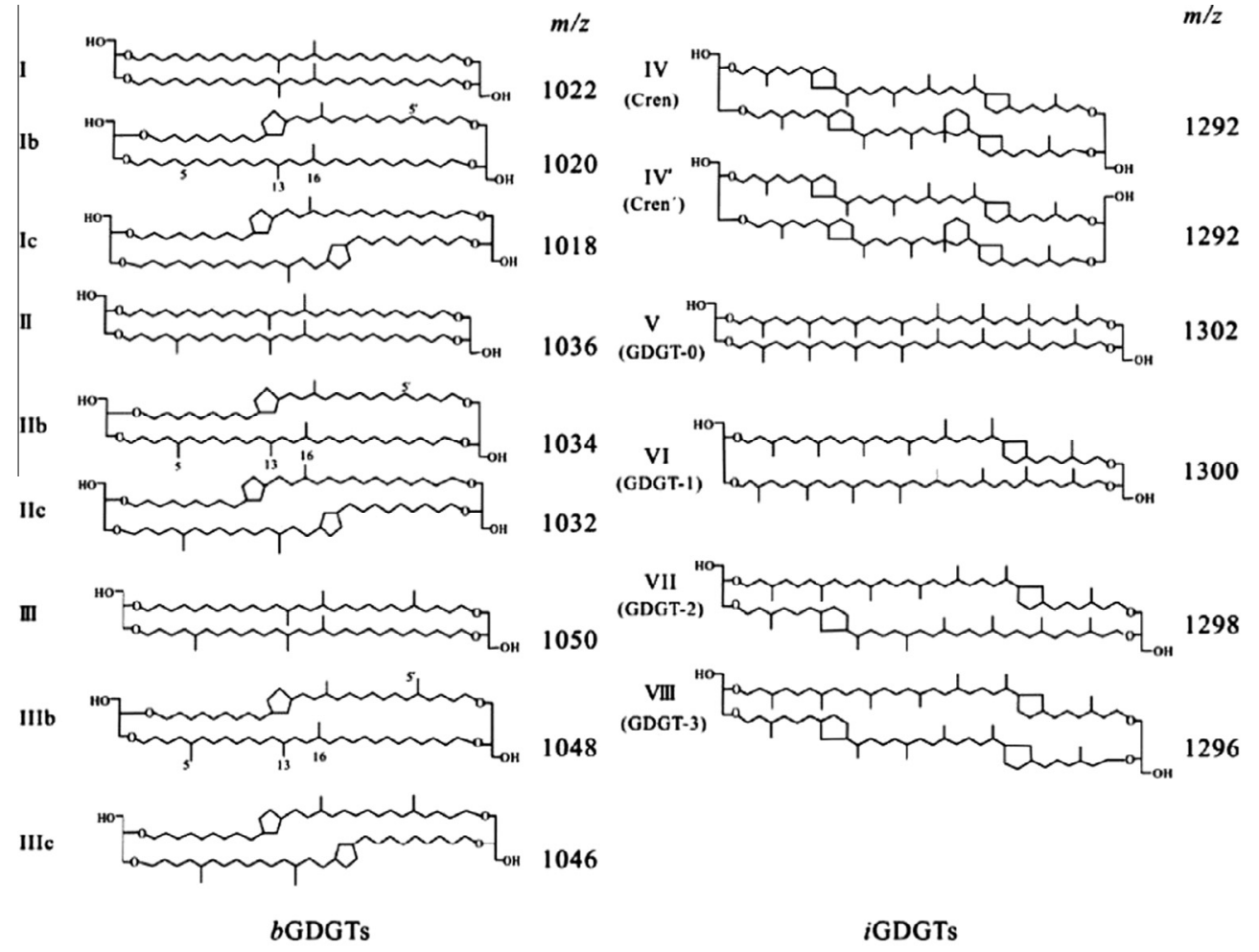

Fig. 2. Structures and abbreviated names of br GDGTs (left) and iso GDGTs (right).

branched and isoprenoid tetraether (BIT) index (Hopmans et al., 2004).

In an attempt to confirm soil as the primary source of the OC transported and discharged by the Changjiang and to constrain its provenance within the catchment, we conducted a preliminary study where we analyzed the bulk properties (proportion of OC (\%) and $\delta^{13} \mathrm{C}$ ) and terrigenous/soil specific biomarkers (lignin phenols and GDGTs) in riverbed surface sediments from different sections of the river basin. Comparison of GDGT signatures from the riverbed sediments with those in soils from corresponding sections of the Changjiang basin was used to assess the contribution of different soil types to the OC transported by the river.

\section{Material and methods}

\subsection{Study area}

The Changjiang lies between $25^{\circ} \mathrm{N}$ and $35^{\circ} \mathrm{N}$ and $90^{\circ} \mathrm{E}$ and $122^{\circ} \mathrm{E}$, covering a total area of $1.81 \times 10^{6} \mathrm{~km}^{2}$, with a change in elevation of $>5400 \mathrm{~m}$. The average annual discharge is ca. $9.6 \times$ $10^{11} \mathrm{~m}^{3}$, with a sediment load of $413 \mathrm{Mt} / \mathrm{yr}$ between 1950 and 2003 (Wang et al., 2011), prior to construction of the Three George Dam (TGD). However, following construction of the dam in 2003 , the sediment flux decreased to $138 \mathrm{Mt} / \mathrm{yr}$ for the period from 2004 to 2011 (Changjiang Sediment Bulletin, 2004-2011). The whole basin can be divided into three major sections: upper, middle and lower reaches according to river slope variation and geographic features (Fig. 1; Chen et al., 2001). The upper reaches can be sub-divided into two segments: the Jinsha reaches and the Chuanjiang reaches (Fig. 1). In the middle and lower reaches, after the dam, two large lakes - Dongting and Poyang - drain into the mainstream of the Changjiang (Fig. 1). The Changjiang catchment is under the influence of different monsoon systems, modulating mean annual precipitation (MAP) across the basin. MAP is ca. $400 \mathrm{~mm}$ at the head of the Jinsha reaches, ca. $700 \mathrm{~mm}$ at the beginning of the middle reaches and ca. $1000 \mathrm{~mm}$ in the lower reaches (Fig. 1). Summer air temperature is generally warm throughout the Changjiang catchment, particularly in the eastern lowlands, where the average July temperature can exceed $30^{\circ} \mathrm{C}$. Winters are mild to cool in the middle and lower reaches, whereas they are very dry and cold, with sub-zero temperature, on the plateau (He et al., 2013).

Soil type also varies along the river. The source area is characterized by alpine meadow soils. In the upper reaches, the major types are yellow-brown, or purple soils, with minor contributions from calcareous soil (limey soil). The middle and lower reaches are dominated by paddy and red soils. There are some additional soil types in the drainage basin, but those mentioned above represent $>60 \%$ area in this river basin (unpublished data).

\subsection{Sample collection and preparation}

Between the source and the estuary of the Changjiang, a total of eight riverbed sediments were collected in September-October 2009, after the wet season in the Changjiang basin (Fig. 1). The bed sediment from the Jinsha River at Shigu station in the source region represents the main source of the mineral load transported by the Changjiang (Xu et al., 2007). Furthermore, three bed sediments in the upper section, two in the middle section, and two in the lower section of the basin were collected. During the sampling period, the water discharge decreased one third in the Datong (Changjiang Sediment Bulletin, 2004-2011). Coordinates, sampling date, distance from the river mouth, water depth, and elevation of the sample locations are given in Table 1 . All bed sediments were collected from the middle of the Changjiang using a $25 \times 25 \mathrm{~cm}$ stainless steel sampler. The surface sediment $(0-2 \mathrm{~cm})$ samples were put into plastic bags and stored frozen at $-20^{\circ} \mathrm{C}$. In the laboratory, the samples were dried at $45{ }^{\circ} \mathrm{C}$ for several days to constant weight. Aliquots of the dried sediments were ground using an agate mortar and pestle, and sieved through an 80 
Table 1

Location and bulk properties of Changjiang riverbed sediments (actual MAT and MAP are from the website of China Meteorological Data Sharing Service System),

\begin{tabular}{|c|c|c|c|c|c|c|c|c|}
\hline Station & Shigu & Nanxi & Jiangjin & Wanzhou & Honghu & Huangshi & Anqing & Xuliujing \\
\hline Location & $\begin{array}{l}\text { Jinsha } \\
\text { reaches }\end{array}$ & $\begin{array}{l}\text { Chuanjiang } \\
\text { reaches }\end{array}$ & $\begin{array}{l}\text { Chuanjiang } \\
\text { reaches }\end{array}$ & $\begin{array}{l}\text { Chuanjiang } \\
\text { reaches }\end{array}$ & $\begin{array}{l}\text { Middle } \\
\text { reaches }\end{array}$ & $\begin{array}{l}\text { Middle } \\
\text { reaches }\end{array}$ & $\begin{array}{l}\text { Lower } \\
\text { reaches }\end{array}$ & $\begin{array}{l}\text { Lower } \\
\text { reaches }\end{array}$ \\
\hline Longitude $\left({ }^{\circ} \mathrm{E}\right)$ & 100.0 & 105.0 & 106.2 & 108.4 & 113.5 & 115.3 & 117.1 & 120.9 \\
\hline Latitude $\left({ }^{\circ} \mathrm{N}\right)$ & 26.9 & 28.8 & 29.3 & 30.8 & 29.8 & 30.2 & 30.5 & 31.8 \\
\hline Date & $2009 / 09 / 09$ & $2009 / 09 / 21$ & $2009 / 09 / 25$ & $2009 / 09 / 30$ & $2009 / 10 / 06$ & $2009 / 10 / 07$ & $2009 / 10 / 08$ & $2009 / 10 / 12$ \\
\hline Altitude (m) & 1820 & 252 & 185 & 103 & 21 & 12 & 5 & 0 \\
\hline Water depth (m) & 7.5 & 4.0 & 5.5 & 35.0 & 6.6 & 15.0 & 11.2 & 14.5 \\
\hline Actual MAT $\left({ }^{\circ} \mathrm{C}\right)$ & 14.6 & 18.1 & 18.4 & 17.7 & 16.6 & 17.0 & 17.2 & 15.4 \\
\hline Precipitation (mm) & 750 & 1076 & 1031 & 1293 & $1060-1331$ & 1383 & $1200-1500$ & 1054 \\
\hline OC $(\%)$ & $0.09 \pm 0.01$ & $0.71 \pm 0.08$ & $0.11 \pm 0.01$ & $0.57 \pm 0.06$ & $0.10 \pm 0.01$ & $0.08 \pm 0.01$ & $0.81 \pm 0.08$ & $0.64 \pm 0.06$ \\
\hline$\delta^{13} \mathrm{C}(\% \circ)$ & $-23.7 \pm 0.1$ & $-24.2 \pm 0.1$ & $-24.6 \pm 0.1$ & $-24.9 \pm 0.1$ & $-24.8 \pm 0.1$ & $-24.1 \pm 0.1$ & $-24.8 \pm 0.1$ & $-25.0 \pm 0.1$ \\
\hline $\begin{array}{l}\text { Median grain size } \\
\qquad(\mu \mathrm{m})\end{array}$ & 88.8 & 32.4 & 117.0 & 14.0 & 139.0 & 142.0 & 14.7 & 12.2 \\
\hline Clay $(<4 \mu \mathrm{m}, \%)$ & 3.10 & 28.5 & 10.5 & 40.3 & 4.6 & 6.5 & 20.6 & 17.9 \\
\hline Silt $(4-63 \mu \mathrm{m}, \%)$ & 32.1 & 64.2 & 44.5 & 58.3 & 23.3 & 28.3 & 76.0 & 80.9 \\
\hline Sand (> $63 \mu \mathrm{m}, \%)$ & 64.9 & 7.3 & 45.0 & 1.4 & 72.1 & 65.2 & 3.4 & 1.2 \\
\hline
\end{tabular}

mesh $(187.5 \mu \mathrm{m})$ sieve prior to further analysis. An other aliquot was used for grain size analysis.

\subsection{Grain size analysis}

Grain size was determined using a laser particle size analyzer (Coulter-LS100Q, Berkman Coulter Corporation, USA) by subdividing each sample into 93 size fractions between $0.2 \mu \mathrm{m}$ and $2 \times 10^{3} \mu \mathrm{m}$. The chemical pretreatment of sediment samples prior to the grain size measurement was described by Luo et al. (2012). For each sample, the mean grain size diameter, along with the relative proportion of clay, silt and sand are reported, for which the particles are classified as $<4 \mu \mathrm{m}, 4-63 \mu \mathrm{m}$ and $>63 \mu \mathrm{m}$, respectively (Trefethen, 1950).

\subsection{Bulk properties (OC and $\delta^{13} \mathrm{C}$ )}

Total OC of the dried and homogenized riverbed sediments was analyzed using an elemental analyzer (CHNOS Vario EL III) and bulk $\delta^{13} \mathrm{C}$ values were measured with a Delta Plus XP mass spectrometer (Thermo Finnigan; Bao et al., 2012a). Samples were treated with $1 \mathrm{M} \mathrm{HCl}$ repeatedly to remove inorganic $C$ prior to analysis at air temperature for $24 \mathrm{~h}$. The accuracy of the OC measurements was determined using the marginal sea sediment (Chinese Standard Material, GBW07309, $0.46 \pm 0.05 \%$ ). The relative standard deviation (RSD) of OC\% based on triplicate measurements was $<5 \%$. The accuracy of $\delta^{13} \mathrm{C}$ was determined using a variety of standard materials including Caffeine (IAEA-600, -27.771 $\pm 0.043 \%$ ), Cellulose (IAEA-CH-3, $-24.724 \pm 0.041 \%$ ), and Black Carbon (the Chinese Standard Material GBW04407, $-22.43 \pm 0.07 \%$ ). The RSD based on triple measurements for $\delta^{13} \mathrm{C}$ measurements was $<0.1 \%$. Isotope ratio values are reported relative to Vienna Peedee Belemnite.

\subsection{Lignin phenols}

Lignin phenols were analyzed using the method described by Yu et al. (2011). In short, the dried and homogenized sediment was placed in a PTFE mini-bomb and digested with $\mathrm{CuO}$, $\mathrm{Fe}\left(\mathrm{NH}_{4}\right)_{2}\left(\mathrm{SO}_{4}\right)_{2}$ in $2 \mathrm{~N} \mathrm{NaOH}$ in the absence of $\mathrm{O}_{2}$ at $160{ }^{\circ} \mathrm{C}$ for $3 \mathrm{~h}$ (Hedges and Ertel, 1982). After cooling to room temperature, $10 \mu \mathrm{g}$ ethyl vanillin (EV) was added as recovery standard, and $\mathrm{HCl}$ (37\%) was used to adjust the $\mathrm{pH}$ to $<2$. Reaction products were extracted with EtOAc, dried, and converted to trimethylsilyl derivatives by using bis(trimethylsilyl)trifluoroacetamide (BSTFA, 99\%)/trimethylchlorosilane (TMCS, 1\%). The resulting lignin phenols were analyzed using gas chromatography (GC) with an Agilent 6890 series GC instrument equipped with a flame ionization detector. Oven temperature was $100^{\circ} \mathrm{C}$ and was then increased to $270{ }^{\circ} \mathrm{C}$ (held $12.5 \mathrm{~min}$ ) at $4{ }^{\circ} \mathrm{C} / \mathrm{min}$. The column was a DB-1 column $(30 \mathrm{~m} \times 0.25 \mathrm{~mm} \times 0.25 \mu \mathrm{m}$, Agilent Technologies, USA).

\subsection{GDGTs}

Dried homogenized sediment (ca. 4-5 g) was extracted with a MARS Xpress microwave extraction system using dichloromethane (DCM): $\mathrm{MeOH}$ 9:1 (v/v). The extract was pipetted off and residues rinsed $2 \times$ with DCM:MeOH (9:1). The combined extract was dried under $\mathrm{N}_{2}$ and a known amount of $\mathrm{C}_{46}$ GDGT standard added. The extract was separated into an apolar and a polar fraction using silica gel column chromatography ( $1 \%$ water deactivated) with hexane:DCM (9:1) and DCM:MeOH (1:1), respectively. The polar fraction (containing the GDGTs) was dried under $\mathrm{N}_{2}$, dissolved in hexane:isopropanol $(99: 1, v / v)$ and filtered over a $0.45 \mu \mathrm{m}$ PTFE filter. The GDGT fraction was analyzed using high performance liquid chromatography-atmospheric pressure chemical ionization mass spectrometry (HPLC-APCI-MS) with an Agilent 1260 Infinity series instrument at ETH Zürich, following Schouten et al. (2007). The injection volume was $10 \mu \mathrm{l}$. Separation of the GDGTs was achieved with an Alltech Prevail Cyano column $(120 \mathrm{~mm} \times 2.1 \mathrm{~mm} ; 3 \mu \mathrm{m})$ preceded by a guard column of the same material, using an elution scheme of $90 \% \mathrm{~A}$ and $10 \% \mathrm{~B}$ for $5 \mathrm{~min}$ and then a linear gradient to $16 \% \mathrm{~B}$ for $34 \mathrm{~min}$, where $\mathrm{A}=$ hexane and $\mathrm{B}=$ hexane:isopropanol $(9: 1, v / v)$. Conditions for APCI-MS were: nebulizer pressure $60 \mathrm{psi}$, vaporizer temperature $300^{\circ} \mathrm{C}$, drying gas $\left(\mathrm{N}_{2}\right)$ flow $6 \mathrm{l} / \mathrm{min}$ and temperature $250{ }^{\circ} \mathrm{C}$, capillary voltage $-3 \mathrm{kV}$, corona $5 \mu \mathrm{A}$ (ca. $3.2 \mathrm{kV}$ ). Selective ion monitoring of the $[\mathrm{M}+\mathrm{H}]^{+}$ions was used to detect the GDGTs. Quantification was achieved by comparing the peak area in the chromatogram that of the internal standard, assuming the $100 \%$ recovery for all GDGTs and a constant response factor for all GDGTs and the standard.

\subsection{GDGT-based proxy calculation}

The BIT index, indicating the relative contribution of soil OC, was calculated according to Hopmans et al. (2004):

$\mathrm{BIT}=\frac{\mathrm{I}+\mathrm{II}+\mathrm{III}}{\mathrm{I}+\mathrm{II}+\mathrm{III}+\text { Cren }}$

The CBT, MBT and $\mathrm{MBT}^{\prime}$ indices, quantifying the degrees of cyclisation and methylation of the br GDGTs were calculated as in Peterse et al. (2012) and Weijers et al. (2007): 
$\mathrm{CBT}=-\log \left(\frac{\mathrm{Ib}+\mathrm{IIb}}{\mathrm{I}+\mathrm{II}}\right)$

$\mathrm{MBT}=\frac{\mathrm{I}+\mathrm{Ib}+\mathrm{Ic}}{\mathrm{I}+\mathrm{Ib}+\mathrm{Ic}+\mathrm{II}+\mathrm{IIb}+\mathrm{IIC}+\mathrm{III}+\mathrm{IIIb}+\text { IIIc }}$

$\mathrm{MBT}^{\prime}=\frac{\mathrm{I}+\mathrm{Ib}+\mathrm{Ic}}{\mathrm{I}+\mathrm{Ib}+\mathrm{Ic}+\mathrm{II}+\mathrm{IIb}+\mathrm{IIC}+\mathrm{III}}$

The structures corresponding to the roman numerals are given in Fig. 2:

MAT was calculated according to the global surface soil calibration of Peterse et al. (2012):

$\mathrm{MAT}^{\prime}=0.81-5.67 \times \mathrm{CBT}+31.0 \times \mathrm{MBT}^{\prime}$

It was also calculated using the transfer function of Yang et al. (2014) derived from (semi)-arid soils in China:

$\mathrm{MAT}=7.5-1.2 \times \mathrm{CBT}+16.1 \times \mathrm{MBT}$

Soil pH was also calculated using the local calibration of Yang et al. (2014):

$\mathrm{pH}=8.68-2.21 \times \mathrm{CBT}$

\subsection{Statistical analysis}

Pearson's correlation analysis was used to determine the significance of the relationships between environmental parameters and biomarker distributions. Cluster analysis and principal component analysis (PCA) were performed to constrain the sources of the GDGTs. SPSS 20.0 software (IBM, SPSS, USA) was used throughout.

\section{Results}

\subsection{Grain size distribution in Changjiang bed sediments}

The mean grain size and the grain size distribution of the bed sediments are given in Table 1 . The grain size of sediment varied irregularly from the upper reaches to the lower reaches, ranging from 12.2 to $142.3 \mu \mathrm{m}$. The coarsest grain size distribution was in the middle reaches and the finest sediment was in the lower reaches. The Wanzhou station in the upper reaches had a smaller mean grain size than the other stations in this section, which may be related to construction of the TGD, which has changed the flow rate in the reservoir area. The clay fraction $(<4 \mu \mathrm{m})$ ranged from $3.1 \%$ to $40.3 \%$; the silt ( $4 \mu \mathrm{m}$ to $64 \mu \mathrm{m}$ ) ranged from $23.3 \%$ to $80.9 \%$ and the sand fraction (> $64 \mu \mathrm{m}$ ) varied from $1.2 \%$ to $72.1 \%$ (Table 1).

\subsection{Bulk properties (OC and $\delta^{13} \mathrm{C}$ ) of Changjiang bed sediments}

The OC content (\%) of the bed sediments varied (Table 1 ) from 0.08 to $0.81 \%$ (avg. $0.39 \pm 0.30, n=8$ ), but did not follow a clear spatial trend. There was a negative correlation between $\mathrm{OC}$ and grain size $\left(r^{2} 0.86, p 0.001\right)$. Bulk $\delta^{13} \mathrm{C}$ values ranged from $-25.0 \%$ o to $-23.7 \%$, with the highest and lowest values occurring at Shigu (Jinsha River, upper reaches) and Xuliujing (close to the river mouth), respectively. There was a trend towards lower values from the source of the river towards the mouth, although absolute changes were minor $(1.3 \%)$.

\subsection{Lignin phenols in Changjiang bed sediments}

The concentrations of vanillyl, syringyl, and cinnamyl lignin phenols are shown in Table 2. $\Sigma 8$ varied from 0.03 to $3.60 \mathrm{mg} / 10 \mathrm{~g} \mathrm{dw}$ (g dry wt); similar to OC, $\Sigma 8$ correlated negatively with grain size $\left(r^{2} 0.72, p 0.008\right)$. However, $\Sigma 8$ did not correlate with the proportion of clay, but did positively correlate with proportion of silt $\left(r^{2} 0.89, p 0.001\right)$. There was also a negative correlation between $\Sigma 8$ and the percentage of sand $\left(r^{2} 0.74, p 0.006\right) . \Lambda 8$ ( $\Sigma 8$ normalized to OC) ranged from 0.36 to $5.66 \mathrm{mg} / 100 \mathrm{mg}$ OC. The lowest values for $\Sigma 8$ and $\Lambda 8$ were at Shigu in the upper reach of the river, whereas the highest values were at Xuliujing station close to the river mouth. Syringyl/vanillyl (S/V) and cinnamyl/vanillyl (C/V) ratios ranged from 0.18 to 2.29 and ca. 0 to 0.42 , respectively (Table 2 ). The $\mathrm{S} / \mathrm{V}$ and $\mathrm{C} / \mathrm{V}$ ratios, indicated a mixed source of angiosperm and gymnosperm plants and woody and non-woody tissue.

\subsection{GDGTs in Changjiang bed sediments}

\subsubsection{Abundance of GDGTs}

All nine br GDGTs were detected in the sediment samples (structures in Fig. 2) and their distribution was dominated by br GDGTs II and III. The total concentration of br GDGTs varied from 0.1 to $7.6 \mu \mathrm{g} / \mathrm{g} \mathrm{dw}$ sediment and from 8.9 to $120.0 \mu \mathrm{g} / \mathrm{g}$ OC. The absolute concentration of br GDGTs negatively correlated negatively with grain size $\left(r^{2} 0.53, p 0.040\right)$. The finer sediments contained higher amounts of br GDGTs than the coarser sediments. After normalizing to OC, the concentration of br GDGTs increased from the upper reaches towards the lower reaches of the Changjiang, especially at the Anqing and Xuliujing stations.

All six iso GDGTs were also present in each sample. The total concentration ranged from $0.03-4.3 \mu \mathrm{g} / \mathrm{g} \mathrm{dw}(3.2-68.1 \mu \mathrm{g} / \mathrm{g} \mathrm{OC})$. The highest values were in the sediments from the lower reach of the river (Table 2). GDGT-0 and Cren were the two most abundant compounds, accounting for $44.0 \pm 11.8 \%$ and $33.4 \pm 8.4 \%$ of all iso GDGTs throughout the catchment, respectively.

Table 2

Lignin, GDGTs and GDGT-based proxy values for Changjiang riverbed sediments.

\begin{tabular}{|c|c|c|c|c|c|c|c|c|}
\hline Station & Shigu & Nanxi & Jiangjin & Wanzhou & Honghu & Huangshi & Anqing & Xuliujing \\
\hline$\Sigma 8(\mathrm{mg} / 10 \mathrm{~g} \mathrm{dw})$ & $0.03 \pm 0.00$ & $2.09 \pm 0.10$ & $0.22 \pm 0.01$ & $1.17 \pm 0.06$ & $0.03 \pm 0.00$ & $0.07 \pm 0.00$ & $2.34 \pm 0.12$ & $3.60 \pm 0.18$ \\
\hline$\Lambda 8(\mathrm{mg} / 100 \mathrm{mg} \mathrm{OC})$ & $0.36 \pm 0.02$ & $2.93 \pm 0.17$ & $1.98 \pm 0.12$ & $2.06 \pm 0.12$ & $2.25 \pm 0.13$ & $0.88 \pm 0.05$ & $2.42 \pm 0.14$ & $5.66 \pm 0.33$ \\
\hline $\mathrm{C} / \mathrm{V}$ & $\sim 0.00 \pm 0.00$ & $0.22 \pm 0.01$ & $0.04 \pm 0.00$ & $0.21 \pm 0.01$ & $0.17 \pm 0.01$ & $0.42 \pm 0.02$ & $0.28 \pm 0.01$ & $0.37 \pm 0.01$ \\
\hline$S / V$ & $0.18 \pm 0.02$ & $0.81 \pm 0.09$ & $2.29 \pm 0.10$ & $0.71 \pm 0.03$ & $0.41 \pm 0.02$ & $1.50 \pm 0.06$ & $0.91 \pm 0.06$ & $1.16 \pm 0.05$ \\
\hline Iso GDGTs (ng/g dw) & 2.9 & 56.5 & 4.9 & 35.1 & 3.9 & 6.2 & 186.5 & 432.8 \\
\hline Br GDGTs (ng/g dw) & 10.0 & 226.7 & 16.0 & 97.3 & 8.7 & 20.8 & 668.6 & 762.4 \\
\hline BIT & 0.91 & 0.87 & 0.86 & 0.89 & 0.70 & 0.83 & 0.89 & 0.83 \\
\hline CBT & 0.45 & 0.44 & 0.41 & 0.35 & 0.02 & 0.11 & 0.31 & 0.27 \\
\hline $\mathrm{pH}(\mathrm{CBT})$ & 7.70 & 7.70 & 7.80 & 7.90 & 8.60 & 8.40 & 8.00 & 8.10 \\
\hline MBT & 0.25 & 0.40 & 0.40 & 0.33 & 0.39 & 0.37 & 0.39 & 0.49 \\
\hline $\mathrm{MBT}^{\prime}$ & 0.25 & 0.41 & 0.40 & 0.34 & 0.40 & 0.38 & 0.40 & 0.50 \\
\hline $\operatorname{MAT}\left({ }^{\circ} \mathrm{C}\right)$ & 10.9 & 13.4 & 13.4 & 12.4 & 13.8 & 13.3 & 13.4 & 15.1 \\
\hline $\mathrm{MAT}^{\prime}\left({ }^{\circ} \mathrm{C}\right)$ & 6.0 & 10.9 & 11.0 & 9.4 & 13.2 & 12.1 & 11.4 & 14.7 \\
\hline
\end{tabular}




\subsubsection{GDGT-based proxies}

Calculated GDGT-based index values are shown in Table 2. Values for the BIT index ranged from 0.70 to 0.91 (avg. $0.85 \pm 0.06$ ). The BIT was highest at Shigu station and lowest at Honghu station, close to the mouth of Dongting Lake in the middle reaches of the Changjiang (Fig. 1). CBT values ranged from 0.02 to 0.45 (avg. $0.29 \pm 0.15$ ) and were lower in the middle and lower reaches $(0.20 \pm 0.10)$ than in the upper reach $(0.40 \pm 0.00)$. The corresponding $\mathrm{pH}$ values, calculated from CBT ranged from 7.7 to 8.6, were higher for the middle and lower reaches $(8.3 \pm 0.3)$ and the upper reach $(7.8 \pm 0.1)$. The MBT index varied from 0.25 to 0.49 (avg. $0.38 \pm 0.06$ ); $\mathrm{MBT}^{\prime}$ varied from 0.25 to 0.50 (avg., $0.39 \pm 0.07)$ and showed no clear spatial trend. MAT, calculated using the CBT and MBT indices and the local calibration (Yang et al., 2014; Eq. 6), ranged from $10.9{ }^{\circ} \mathrm{C}$ to $15.1^{\circ} \mathrm{C}$, slightly lower than the actual MAT (from the website of China Meteorological Data Sharing Service System). MAT' (Peterse et al., 2012: Eq. 5) varied from $6.0^{\circ} \mathrm{C}$ to $14.7^{\circ} \mathrm{C}$ and underestimated the actual temperatures (Tables 1 and 2). There was a positive correlation between the calculated MAT and MAT', however, neither calculated value was correlated with the actual MAT.

\section{Discussion}

\subsection{Assessment of $O C$ source based on $\delta^{13} \mathrm{C}$ and lignin phenols}

The carbon isotopic values of the Changjiang bed sediment-associated OC ( $-25.0 \%$ to $-23.7 \%$; Fig. 3) are slightly higher than those reported for SPM collected in 2003 (-26.6\% to $-24.4 \%$; Wu et al., 2007). However, as previously observed there is no clear variation along the course of the river. Both sediment and SPM $\delta{ }^{13} \mathrm{C}$ values are similar to those reported for plants and soils along the river (Yu et al., 2007). In big river systems, it can be inferred that potential $O C$ sources include fresh plants, soils in the drainage basin, phytoplankton in the water column, and sedimentary rock from the watershed (Eglinton, 1994; Galy et al., 2008b; Yu et al., 2011; Tao et al., 2015). Average $\delta^{13} \mathrm{C}$ values for vegetation along the Changjiang and its tributaries have been reported to vary between $-29.7 \%$ and $-26.1 \%$ (Yu et al., 2007), consistent with a predominance of $C_{3}$ plants (Still et al., 2003).

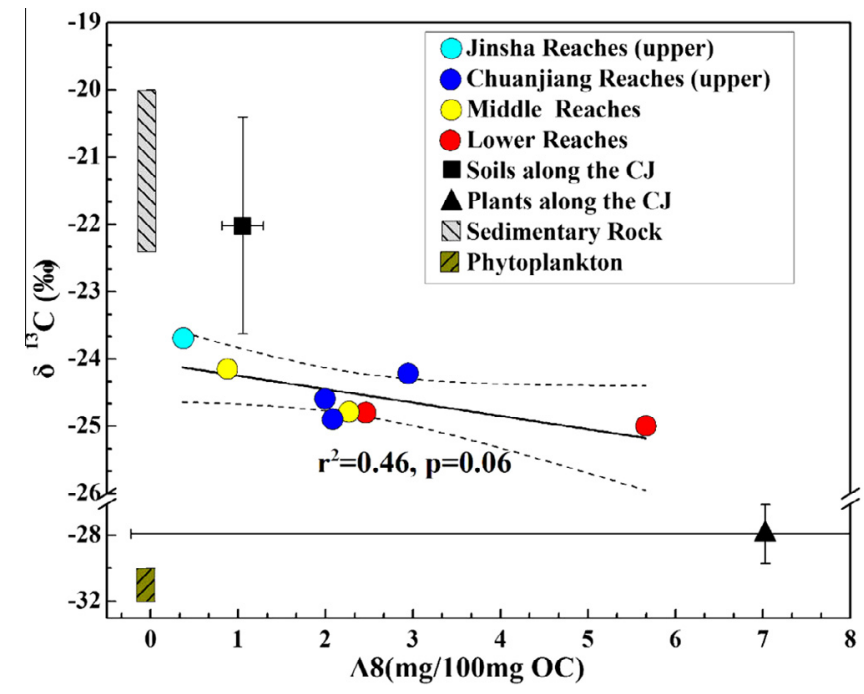

Fig. 3. Plot of $\delta^{13} \mathrm{C}$ values of total OC vs. OC-normalized lignin concentration $(\Lambda 8)$ in Changjiang River sediments (dashed lines represent 95\% confidence interval). The soil and plant values are from Yu et al. (2011), the range of $\delta^{13} \mathrm{C}$ values in the phytoplankton was calculated from the $\delta^{13} \mathrm{C}$ values of DIC in the Changjiang according to Mayorga et al. (2005), and the range of $\delta^{13} \mathrm{C}$ values in the sedimentary rock in the Changjiang Basin is from Liu et al. (2007).
Yu et al. (2007) analyzed the $\delta^{13} \mathrm{C}$ values of common soils along the Changjiang River, and found that those for paddy, yellow and purple soils averaged $-22.2 \pm 2.0 \%, \quad-22.3 \pm 2.0 \%$ and $-21.7 \pm 1.2 \%$, respectively. The average $\delta^{13} \mathrm{C}$ value of soil across Changjiang basin is $-22.0 \pm 1.6 \%$ (Yu et al., 2007). A similar range $(-24.5$ to $-21.1 \%$ ) for different soils in the catchment was also reported by Zhu et al. (2006). Depending on the source(s) of dissolved inorganic $\mathrm{C}$ used during photosynthesis, phytoplankton produced in freshwater systems often have lower ${ }^{13} \mathrm{C}$ values than higher plants (Hedges et al., 1986; Tan and Edmond, 1993). To the best of our knowledge, there are no reports of phytoplankton $\delta^{13} \mathrm{C}$ values for Changjiang, but the $\delta^{13} \mathrm{C}$ content can be estimated from available $\delta^{13} \mathrm{C}$ values of dissolved inorganic $\mathrm{C}$ (DIC) in the river due to the nearly constant concentration of $\mathrm{CO}_{2}$ in the river water (Chanton and Lewis, 1999; Mayorga et al., 2005). The $\delta^{13} \mathrm{C}$ values of DIC in the river range from $-12.2 \%$ to $-9.9 \%$ during the phytoplankton growing season (Patra et al., 2010; Wu et al., 2012), which is subsequently fractionated by ca. $-20.0 \%$ o upon uptake by phytoplankton (Mayorga et al., 2005), resulting in $\delta^{13} \mathrm{C}$ values in the range $-32.0 \%$ o to $-30.0 \%$. Recently, contributions of sedimentary rock $C$ to river systems has been discussed for big river systems such as the Ganges River and Huanghe River system (Galy et al., 2008b; Tao et al., 2015). In the Changjiang River, there have not been any studies to assess the contribution of sedimentary rock to the OC. Liu et al. (2007) analyzed the $\delta^{13} \mathrm{C}$ values of sedimentary rock in the Qing-Tibet Plateau, and found an average values of $-21.2 \% \circ( \pm 1.2 \%$ ), which is in the same range as that covered by the soils in the Changjiang basin (Fig. 3). The $\delta^{13} \mathrm{C}$ values for Changjiang sedimentary $\mathrm{OC}$ lie between those of the discussed sources, suggesting that the $\mathrm{OC}$ in the Changjiang comprises a mixture of these. However, the $\delta^{13} \mathrm{C}$ values of river sediments $(-25.0 \%$ to $-23.7 \%$ ) are positive relative to phytoplankton $(-32.0 \%$ to $-30.0 \%$ ), which indicates that the contribution of phytoplankton to the sedimentary $\mathrm{OC}$ is likely minor. Based on $\delta^{13} \mathrm{C}$ values, $\mathrm{C}_{3}$ plants and soils or rock $C$ are the main $O C$ sources in the Changjiang bed sediments.

Another perspective on the origin of the OM in the Changjiang sediments stems from analysis of the higher plant-derived lignin phenols. In the Changjiang sediments, the average lignin content $(\Lambda 8,0.36$ to $5.66 \mathrm{mg} / 100 \mathrm{mg}$ OC; Fig. 3 ) is lower than that of higher plants ( 1 to $11 \mathrm{mg} / 100 \mathrm{mg}$ OC) and higher than that of soils $(1.05 \pm 0.24 \mathrm{mg} / 100 \mathrm{mg}$ OC; Yu et al., 2007) in the Changjiang basin. Plotting sedimentary $\delta^{13} \mathrm{C}$ values against $\Lambda 8$ reveals a negative correlation between $\delta^{13} \mathrm{C}$ and $\Lambda 8\left(r^{2} 0.46, p 0.06\right)$, indicating that the $\mathrm{OC}$ in the bed sediments matches a mixture of plants and catchment soil material, consistent with the $\delta{ }^{13} \mathrm{C}$ data (Fig. 3). However, since soil and sedimentary rock have comparable $\delta^{13} \mathrm{C}$ values, it is difficult to distinguish the contribution of each of those sources to the total OC. Galy et al. (2008b) found that in the Ganga-Brahmaputra River system, coarse grained sediments with a low OC content contained a higher contribution of sedimentary rock-derived C. In this study, the sediments at Shigu, Jiangjin, Honghu and Huangshi stations were coarse $(>88.9 \mu \mathrm{m})$, and have a low OC content $(<0.11 \%)$. As a result, it is possible that sedimentary rock indeed contributes to the OC at these stations. However, the exact contribution of sedimentary rocks to the TOC is hard to determine due to the lack of necessary (radiocarbon) data.

\subsection{Constraints on soil OC provenance from GDGT distributions}

Although the $\delta^{13} \mathrm{C}$ and lignin content indicate that the $\mathrm{OC}$ in the river sediments is at least partially soil derived, these parameters cannot distinguish between inputs from different soil types in the drainage basin. The type of soil in the Changjiang basin varies along the river and includes, for example, plateau soil, limey soil, yellow soil, purple soil and paddy soil. The plateau soil occurs in 


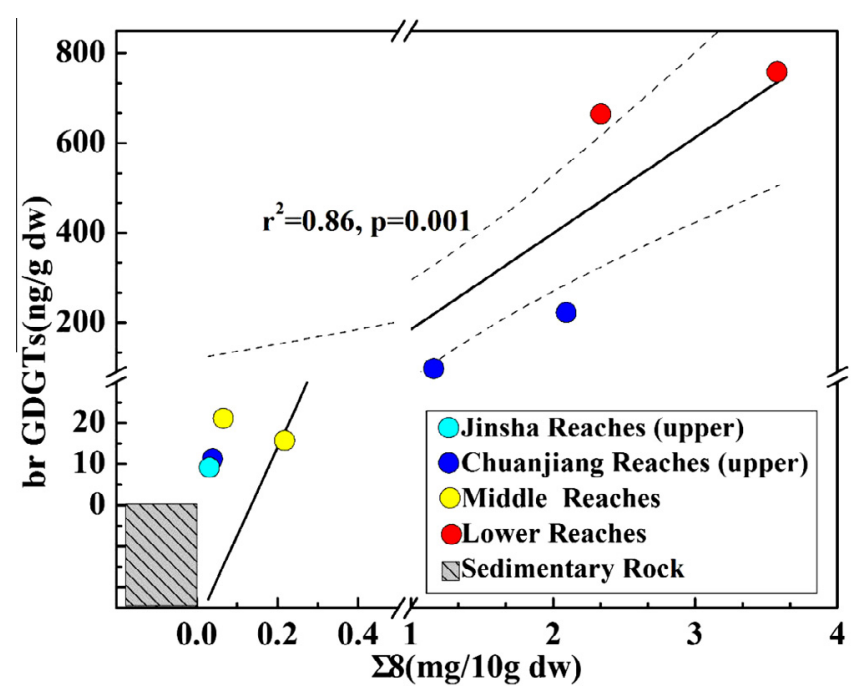

Fig. 4. Plot of br GDGT concentration vs. lignin concentration $(\Sigma 8)$ (dashed lines represent $95 \%$ confidence interval).

the upper Jinsha reach, where the climate is cooler and dryer than in the middle and lower reaches (Fig. 1). The yellow, limy and purple soils can be found in parts of the upper and middle reaches with wet climate conditions, whereas the paddy soils are widely scattered over the middle and lower reaches of the Changjiang (Fig. 1). Due to the diversity of environmental conditions and physicochemical properties of these soils (such as temperature, soil $\mathrm{pH}$ and moisture availability), different soil types may potentially be distinguished on the basis of their br GDGTs signatures, serving as a means of establishing the provenance of the soil OC contributing to the riverine load. However, recent studies have revealed that br GDGTs transported by rivers are not necessarily exclusively derived from the surrounding soils, but may also be produced in situ (Zhu et al., 2011; Kim et al., 2012; Yang et al., 2013; Zell et al., 2013; De Jonge et al., 2014). Thus initial soil br
GDGT signals may be modified, confounding assessment of provenance and resulting in unreliable br GDGT-based paleotemperature reconstruction and $\mathrm{pH}$ reconstruction from fluvial-influenced sediments (Zell et al., 2013; De Jonge et al., 2014). Nevertheless, studies have suggested that br GDGTs of aquatic origin are of minor importance in the sections of the Changjiang studied so far, namely in the vicinity of the TGD (Yang et al., 2013) and in the lower reaches (Zhu et al., 2011). Furthermore, the lignin content strongly correlates with the concentration of br GDGTs in the sediments $\left(r^{2} 0.86, p 0.001\right.$; Fig. 4), suggesting that these two biomarkers have a common vector of supply, likely via soil erosion.

A br GDGT signature for each of the main soil types in the river basin can be established from distributions reported in earlier studies of soils from the basin (Wang et al., 2012; Xie et al., 2012; Yang et al., 2012, 2014; Ayari et al., 2013). Cluster analysis was performed on the fractional abundance of the different br GDGTs in the soils and river sediments to determine the provenance of br GDGTs in the river sediments. This clearly shows that the sediments and soils in the basin cluster into three groups (Fig. 5). The first consists of the Shigu station in the upper reaches, as well as plateau soils. The second includes the Huangshi and Honghu stations, which are grouped with the limey soils that occur widely in the middle reaches of the river. The third group contains the stations from both the upper and lower reaches, and clusters with the yellow and purple soils in that area. This clustering suggests that the br GDGTs in the Changjiang sediments are strongly related to those of nearby soils, implying that br GDGTs in the river reflect local rather than an integrated basin-wide signal.

To verify the outcome of the cluster analysis, we also performed principal component analysis (PCA) on the distribution of br GDGTs in the sediments and soils. The first two PCA axes (PC1 and PC2) explain $78.4 \%$ of the variance in the br GDGT data (Fig. 6A). With respect to the loadings of specific br GDGTs, types III and II clearly plot opposite from all other br GDGTs on axis PC1. On the PC2 axis, types IIIb and IIb plot opposite to I (Fig. 6A). The score plots reveal that the Qinghai-Tibet Plateau soils (> $3000 \mathrm{~m}$ altitude; upper left quadrant in Fig. 6B), clearly separate

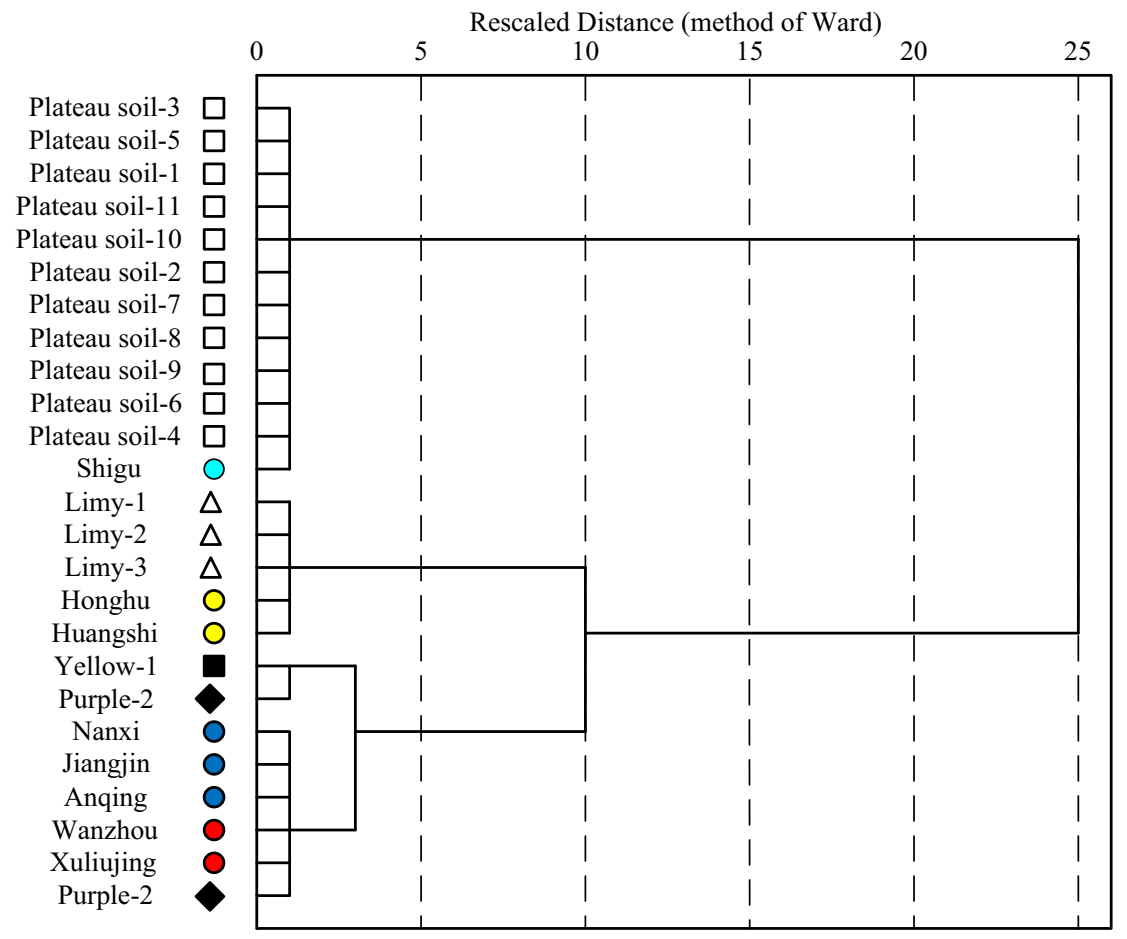

Fig. 5. Cluster analysis showing relationship between br GDGT distributions in Changjiang sediments and catchment soils. 

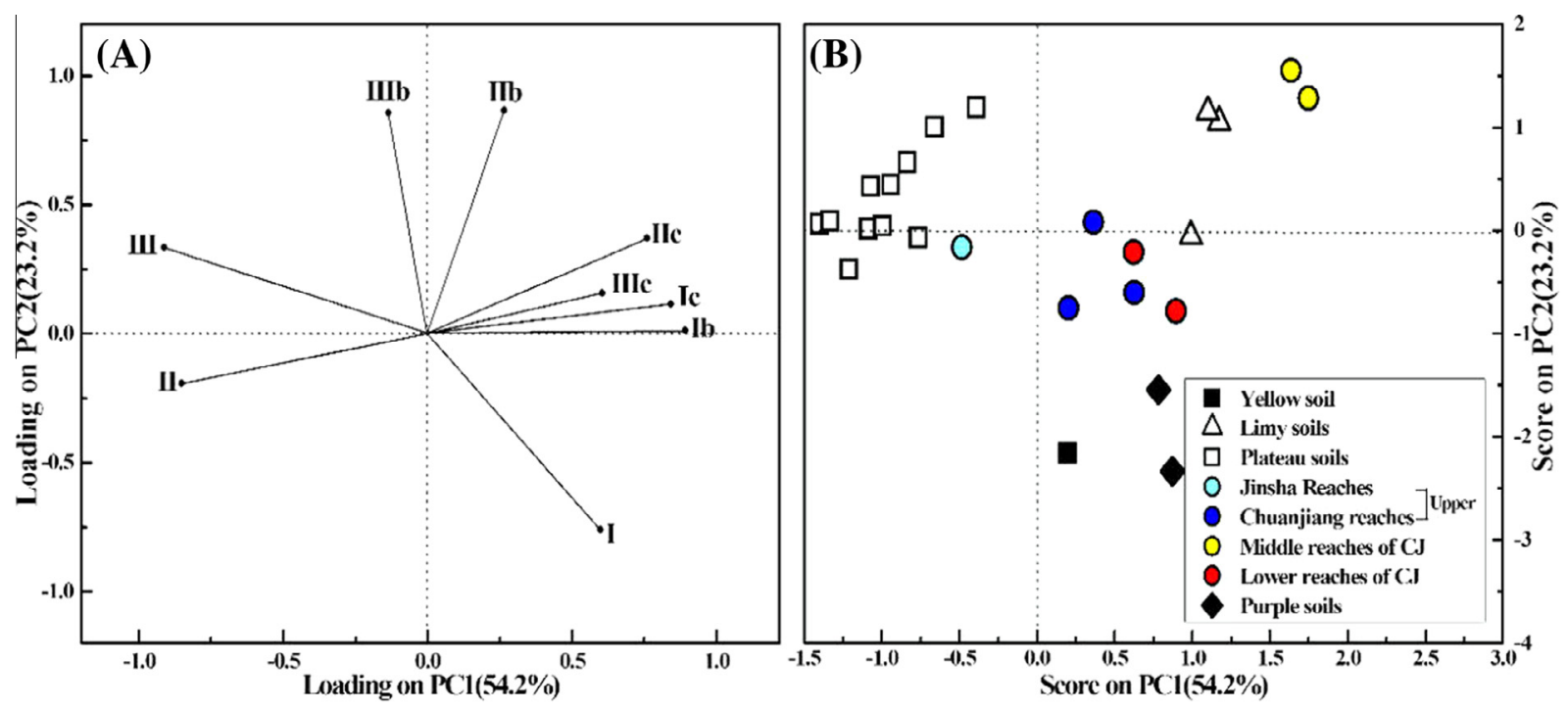

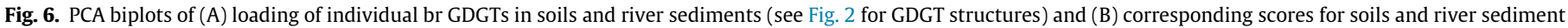
samples from the Changjiang basin.

from the limey, yellow and purple soils in the lower reaches of the catchment. The latter are further separated into two groups: the limey soils from the middle reaches plot mainly in the upper right quadrant, whereas the purple yellow soils plot in the lower right quadrant (Fig. 6B). PCA scores for the river sediments support the results of cluster analysis (Figs. 5 and 6B). The br GDGT composition at Shigu is closest to that of the Qinghai-Tibet Plateau soils, suggesting that soil erosion on the plateau is the primary source of br GDGTs in the river. The separation of this station from the other sediments indicates that the plateau soil br GDGTs are either degraded during river transport, or that their signature is diluted by the input of br GDGTs derived from local soils further downstream (Fig. 6B). Indeed, the other two sediments from the upper reaches already show a more mixed soil source. Also, the sediments from Honghu and Huangshi in the middle reaches plot with the more limey soils from the adjacent Hubei province (Fig. 6B). Although the br GDGT signal in the river sediments cannot be accurately apportioned into local, upstream and in situ components, our results lend support to the notion of preferential degradation of fresh, allochthonous OC during river transport (Mayorga et al., 2005; Butman and Raymond, 2011).

The br GDGT composition varies independently from the mineral load in the Changjiang. He et al. (2013) found that the major part of the mineral fraction transported by the river is derived from the plateau and that the clay mineral composition displays a relatively constant pattern along the main stem, with minor alteration from the different tributaries. The contrast between the downstream variation in br GDGT distributions and the uniformity of the mineral composition provides another indication that soil br GDGTs supplied to the river from the plateau must be partially oxidized and replaced by local OM during transport.

\subsection{Source of iso GDGTs in Changjiang sediments}

The most abundant iso GDGTs in the river sediments are iso GDGT-0 and crenarchaeol. Crenarchaeol originates from a unique group of Thaumarchaeota, whereas GDGT-0 is produced by an array of archaea, including methanogens (Schouten et al., 2013 and references therein). The ratio of iso GDGT-0:crenarchaeol has been proposed to distinguish the main sources of these compounds, with values $<2$ pointing towards Thaumarchaeota as the main iso GDGT source, and values $>2$ indicating a contribution from methanogens (Blaga et al., 2009). The iso GDGT-0:crenarchaeol ratio in the river sediments varies between 0.4 and 2.3 (Fig. 7), suggesting a minor contribution of methanogens at some locations. These values are in the same range as reported by Yang et al. (2013), who studied the distribution of iso GDGTs in the water column of the Three Gorges Reservoir. Similar values were reported for the lower reaches of the river (1.96 on average; Zhu et al., 2011). Although these studies concluded that most iso GDGTs are produced by archaea in the river, the relatively high BIT index values (Zhu et al., 2011; Yang et al., 2013; this study) indicate substantial input of soil material that may also include iso GDGTs. Indeed, the concentration of iso GDGTs exhibits a positive correlation with that of br GDGTs $\left(r^{2}\right.$ $0.89, p<0.001$; Table 3 ), suggesting that the grain size of bed sediments might be a key factor in controlling the OC loading in the Changjiang. As for the river sediments, GDGT-0 and crenarchaeol are the most common iso GDGTs in the different soil types in the catchment (Wang et al., 2012; Yang et al., 2012, 2014; Ayari et al., 2013). However, comparison of the ratios between iso

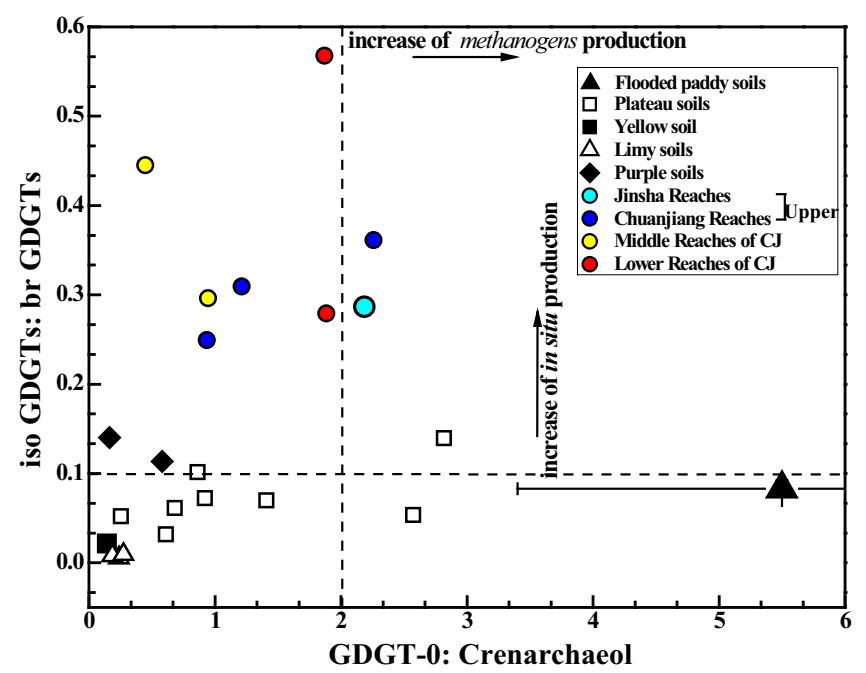

Fig. 7. Cross plot of GDGT-0:Cren vs. iso GDGTs:br GDGTs in Changjiang River sediments and surrounding soils. 
Table 3

Correlation coefficient (and $p$ value) of terrestrial/soil parameters for Changjiang bed sediments.

\begin{tabular}{|c|c|c|c|c|c|c|c|}
\hline & $\delta^{13} \mathrm{C}(\%)$ & $\Lambda 8(\mathrm{mg} / 100 \mathrm{mg} \mathrm{OC})$ & Br GDGTs (ng/g OC) & Iso GDGTs (ng/g OC) & $\mathrm{I}+\mathrm{II}+\mathrm{III}(\mathrm{ng} / \mathrm{g} \mathrm{OC})$ & Cren (ng/g OC) & BIT \\
\hline$\delta^{13} \mathrm{C}(\%)$ & 1.00 & $-0.68(0.06)$ & $-0.48(0.22)$ & $-0.50(0.21)$ & $-0.48(0.23)$ & $-0.50(0.20)$ & $0.34(0.42)$ \\
\hline$\Lambda 8(\mathrm{mg} / 100 \mathrm{mg} \mathrm{OC})$ & & 1.00 & $0.80^{*}(0.02)$ & $0.87^{* *}(0.00)$ & $0.80^{*}(0.02)$ & $0.88^{* *}(0.00)$ & $-0.19(0.64)$ \\
\hline Br GDGTs (ng/g OC) & & & 1.00 & $0.94^{* *}(0.00)$ & $1.00^{* * *}(0.00)$ & $0.96^{* *}(0.00)$ & $0.11(0.80)$ \\
\hline Iso GDGTs (ng/g OC) & & & & 1.00 & $0.93^{* *}(0.00)$ & $0.99^{* *}(0.00)$ & $-0.02(0.96)$ \\
\hline $\mathrm{I}+\mathrm{II}+\mathrm{III}(\mathrm{ng} / \mathrm{g} \mathrm{OC})$ & & & & & 1.00 & $0.95^{* *}(0.00)$ & $0.15(0.72)$ \\
\hline Cren (ng/g OC) & & & & & & 1.00 & $-0.05(0.91)$ \\
\hline BIT & & & & & & & 1.00 \\
\hline
\end{tabular}

* $p \leqslant 0.05$

*** $p \leqslant 0.01$

GDGT-0:crenarchaeol and the iso GDGT:br GDGT concentrations in soils and sediments indicates that part of the iso GDGTs is likely produced in the river (Fig. 7). Also the BIT index indicates an aquatic contribution to the iso GDGTs, as it is lower in the sediments (> 0.70) than in the nearby soils (>0.88; Ayari et al., 2013; Yang et al., 2014). Nevertheless, the relatively high BIT index values confirm that the contribution of aquatic production to the sedimentary $\mathrm{OC}$ is only minor in this river.

\subsection{Implications for interpretation of $M B T-C B T$ derived temperatures}

The actual mean air temperature in each station was obtained from the website of China Meteorological Data Sharing Service System (Table 1) and has no correlation with the altitude. This may be due to the fact that the annual temperature of the city near the sampling station was used here. The MBT-CBT derived MAT (Yang et al., 2014) in the Changjiang bed sediments varies from $10.9{ }^{\circ} \mathrm{C}$ at Shigu to $15.0^{\circ} \mathrm{C}$ at Xuliujing, and generally follows the adiabatic warming of air with the decrease in elevation from the source towards the river mouth. There is also a negative correlation between the br GDGT-derived MAT (based on Yang et al., 2014) and altitude $\left(r^{2} 0.65, p\right.$ 0.010) (Table 2). However, this calculated MAT is ca. $4{ }^{\circ} \mathrm{C}$ lower than the actual MAT. This offset may be explained by an temperature signal that represents the area upstream of the sampling location. Also, $\mathrm{MAT}^{\prime}$ (based on Peterse et al., 2014; Table 2), underestimates the actual MAT.

The adiabatic change in temperature with changing elevation may be expressed as the temperature lapse rate $\left({ }^{\circ} \mathrm{C} / 1000 \mathrm{~m}\right)$. The lapse rate based on br GDGT derived MAT is $-1.6^{\circ} \mathrm{C} / 1000 \mathrm{~m}$ for the Changjiang basin and is similar to the temperature lapse rate of $-1.3^{\circ} \mathrm{C} / 1000 \mathrm{~m}$ based on weather station data (China Meteorological Data Sharing Service System). However, the GDGT-based lapse rate for the basin is lower than the average rate of $-3.6 \pm 0.6{ }^{\circ} \mathrm{C} / 1000 \mathrm{~m}$ determined for Southeast Asia on the basis of all altitudinal transects studied thus far (Ernst et al., 2013).

The evolving br GDGT signature along the course of the river has implications for interpretation of paleoclimate records based on br GDGTs distributions in river-dominated marine sediment cores, as they have been interpreted as representative of the integrated drainage basin (e.g. Weijers et al., 2007; Bendle et al., 2010). The br GDGT distributions in Changjiang sediments indicate that, although br GDGTs discharged to the marine environment are indeed mainly soil derived, br GDGT signals are strongly modulated by local input rather than one integrated soil input from the entire drainage basin. Previous work has also indicated that the contribution of in situ-produced br GDGTs increases towards the mouth of the Changjiang (Zhu et al., 2011). Hence, in the case of the this river, downcore applications of the MBT-CBT proxy should more likely result in a record of the climatic variability in the lower reaches of the catchment than one that is representative of the entire basin.

\section{Conclusions}

The stable carbon isotope, lignin phenol and GDGT composition of sediments of the Changjiang provide complementary perspectives on the sources and evolution of OC signals transported downstream by, and exported from, the river. The $\delta^{13} \mathrm{C}$ values and lignin phenol abundance indicate that source of the $O C$ in the bed sediments reflects a mixture of primarily fresh $C_{3}$ plants and soils in the catchment. Br GDGTs are mainly soil-derived, whereas iso GDGT may also contain an aquatic component. Comparison of br GDGT distributions in riverbed sediments with those in soils throughout the river basin suggests an important contribution from plateau soils to fluvial sediments in the upper part of the catchment. However, this signal is attenuated and replaced by an input from local soils during downstream transport. These evolving sedimentary br GDGT distributions imply that br GDGTs exported from the river and deposited in offshore sedimentary sequences should likely reflect local conditions, rather than basin-integrated climate conditions in the Changjiang drainage basin.

\section{Acknowledgements}

The study was funded by the Natural Science Foundation of China (Grant Nos. 41021064 and 41276081), the National Key Basic Research Program from the Ministry of Science and Technology of China (No. 2010 DFA 24590) and the 111 Project (No. B08022). The authors thank all members in the Marine Biogeochemistry Group for assistance with fieldwork, and we also greatly appreciate the constructive suggestions and comments from two anonymous reviewers, which helped improve the manuscript.

\section{Appendix A. Supplementary data}

Supplementary data associated with this article can be found, in the online version, at http://dx.doi.org/10.1016/j.orggeochem. 2015.04.006.

\section{Associate Editor-E.A. Canuel}

\section{References}

Ayari, A., Yang, H., Xie, S., 2013. Flooding impact on the distribution of microbial tetraether lipids in paddy rice soil in China. Frontiers of Earth Science 7, 384394

Bao, H., Wu, Y., Unger, D., Du, J., Herbeck, L.S., Zhang, J., 2012a. Impact of the conversion of mangroves into aquaculture ponds on the sedimentary organic matter composition in a tidal flat estuary (Hainan Island, China). Continental Shelf Research 57, 82-91.

Bao, H., Wu, Y., Zhang, J., Deng, B., He, Q., 2012b. Composition and flux of suspended organic matter in the middle and lower reaches of the Changjiang (Yangtze River) - impact of the Three Gorges Dam and the role of tributaries and channel erosion. Hydrological Processes 28, 1137-1147. 
Bendle, J.A., Weijers, J.W.H., Maslin, M.A., Sinninghe Damsté, J.S., Schouten, S., Hopmans, E.C., Boot, C.S., Pancost, R.D., 2010. Major changes in glacial and Holocene terrestrial temperatures and sources of organic carbon recorded in the Amazon fan by tetraether lipids. Geochemistry, Geophysics, Geosystems 11, Q12007.

Blaga, C., Reichart, G.-J., Heiri, O., Sinninghe Damsté, J., 2009. Tetraether membrane lipid distributions in water-column particulate matter and sediments: a study of 47 European lakes along a north-south transect. Journal of Paleolimnology 41, 523-540.

Blair, N.E., Leithold, E.L., Aller, R.C., 2004. From bedrock to burial: the evolution of particulate organic carbon across coupled watershed-continental margin systems. Marine Chemistry 92, 141-156.

Butman, D., Raymond, P.A., 2011. Significant efflux of carbon dioxide from streams and rivers in the United States. Nature Geoscience 4, 839-842.

Changjiang Sediment Bulletin, 2004. Press of Ministry of Water Resources of the People's Republic of China. Website: <http://www.cjh.com.cn/>.

Changjiang Sediment Bulletin, 2005. Press of Ministry of Water Resources of the People's Republic of China. Website: <http://www.cjh.com.cn/>.

Changjiang Sediment Bulletin. 2006. Press of Ministry of Water Resources of the People's Republic of China. website: http://www.cjh.com.cn/.

Changjiang Sediment Bulletin, 2007. Press of Ministry of Water Resources of the People's Republic of China. Website: <http://www.cjh.com.cn/>.

Changjiang Sediment Bulletin, 2008. Press of Ministry of Water Resources of the People's Republic of China. Website: <http://www.cjh.com.cn/>.

Changjiang Sediment Bulletin, 2009. Press of Ministry of Water Resources of the People's Republic of China. Website: <http://www.cjh.com.cn/>.

Changjiang Sediment Bulletin, 2010. Press of Ministry of Water Resources of the People's Republic of China. Website: <http://www.cjh.com.cn/>.

Changjiang Sediment Bulletin, 2011. Press of Ministry of Water Resources of the People's Republic of China. Website: <http://www.cjh.com.cn/>.

Chanton, J.P., Lewis, F.G., 1999. Plankton and dissolved inorganic carbon isotopic composition in a river-dominated estuary: Apalachicola Bay, Florida. Estuaries 22, 575-583.

Chen, Z., Li, J., Shen, H., Wang, Z., 2001. Yangtze River of China: historical analysis of discharge variability and sediment flux. Geomorphology 41, 77-91.

Damsté, J.S.S., Rijpstra, W.I.C., Hopmans, E.C., Schouten, S., Balk, M., Stams, A.J., 2007. Structural characterization of diabolic acid-based tetraester, tetraether and mixed ether/ester, membrane-spanning lipids of bacteria from the order Thermotogales. Archives of Microbiology 188, 629-641.

De Jonge, C. Stadnitskaia, A., Hopmans, E.C., Cherkashov, G., Fedotov, A., Sinninghe Damsté, J.S., 2014. In situ produced branched glycerol dialkyl glycerol tetraethers in suspended particulate matter from the Yenisei River, Eastern Siberia. Geochimica et Cosmochimica Acta 125, 476-491.

De Rosa, M., Gambacorta, A., 1988. The lipids of archaebacteria. Progress in Lipid Research 27, 153-175.

Eglinton, T.I., 1994. Carbon isotopic evidence for the origin of macromolecular aliphatic structures in kerogen. Organic Geochemistry 21, 721-735.

Ernst, N., Peterse, F., Breitenbach, S.F., Syiemlieh, H.J., Eglinton, T.I., 2013. Biomarkers record environmental changes along an altitudinal transect in the wettest place on Earth. Organic Geochemistry 60, 93-99.

Galy, V., France-Lanord, C., Beyssac, O., Faure, P., Kudrass, H., Palhol, F., 2007. Efficient organic carbon burial in the Bengal fan sustained by the Himalayan erosional system. Nature 450, 407-410.

Galy, V., Beyssac, O., France-Lanord, C., Eglinton, T., 2008a. Recycling of graphite during Himalayan erosion: a geological stabilization of carbon in the crust. Science 322, 943-945.

Galy, V., France-Lanord, C., Lartiges, B., 2008b. Loading and fate of particulate organic carbon from the Himalaya to the Ganga-Brahmaputra delta. Geochimica et Cosmochimica Acta 72, 1767-1787.

Goñi, M.A., Yunker, M.B., Macdonald, R.W., Eglinton, T.I., 2000. Distribution and sources of organic biomarkers in arctic sediments from the Mackenzie River and Beaufort Shelf. Marine Chemistry 71, 23-51.

Hamilton, S., Lewis Jr, W., 1992. Stable carbon and nitrogen isotopes in algae and detritus from the Orinoco River floodplain, Venezuela. Geochimica et Cosmochimica Acta 56, 4237-4246.

He, M., Zheng, H., Huang, X., Jia, J., Li, L., 2013. Yangtze River sediments from source to sink traced with clay mineralogy. Journal of Asian Earth Sciences 69, 60-69.

Hedges, J.I., 1992. Global biogeochemical cycles: progress and problems. Marine Chemistry 39, 67-93.

Hedges, J.I., Ertel, J.R., 1982. Characterization of lignin by gas capillary chromatography of cupric oxide oxidation products. Analytical Chemistry 54, 174-178.

Hedges, J.I., Clark, W.A., Quay, P.D., Richey, J.E., Devol, A.H., Santos, U.d.M., 1986. Compositions and fluxes of particulate organic material in the Amazon River. Limnology and Oceanography 31, 717-738.

Hedges, J.I., Blanchette, R.A., Weliky, K., Devol, A.H., 1988. Effects of fungal degradation on the $\mathrm{CuO}$ oxidation products of lignin: a controlled laboratory study. Geochimica et Cosmochimica Acta 52, 2717-2726.

Hedges, J.I., Keil, R., Benner, R., 1997. What happens to terrestrial organic matter in the ocean? Organic Geochemistry 27, 195-212.

Hopmans, E.C., Weijers, J.W., Schefuß, E., Herfort, L., Sinninghe Damsté, J.S., Schouten, S., 2004. A novel proxy for terrestrial organic matter in sediments based on branched and isoprenoid tetraether lipids. Earth and Planetary Science Letters 224, 107-116.

Kim, J.-H., Zell, C., Moreira-Turcq, P., Pérez, M.A., Abril, G., Mortillaro, J.-M., Weijers, J.W., Meziane, T., Sinninghe Damsté, J.S., 2012. Tracing soil organic carbon in the lower Amazon River and its tributaries using GDGT distributions and bulk organic matter properties. Geochimica et Cosmochimica Acta 90, 163-180.

Lal, R., 2003. Soil erosion and the global carbon budget. Environment International 29, 437-450.

Langworthy, T.A., Tornabene, T., Holzer, G., 1982. Lipids of archaebacteria. Zentralblatt für Bakteriologie Mikrobiologie und Hygiene: I. Abt. Originale C: Allgemeine, Angewandte und Okologische Mikrobiologie 3, 228-244.

Liu, W., Yang, H., Ning, Y., An, Z., 2007. Contribution of inherent organic carbon to the bulk $\delta{ }^{13} \mathrm{C}$ signal in loess deposits from the arid western Chinese Loess Plateau. Organic Geochemistry 38, 1571-1579.

Luo, X.X., Yang, S.L., Zhang, J., 2012. The impact of the Three Gorges Dam on the downstream distribution and texture of sediments along the middle and lower Yangtze River (Changjiang) and its estuary, and subsequent sediment dispersal in the East China Sea. Geomorphology 179, 126-140.

Mayorga, E., Aufdenkampe, A.K., Masiello, C.A., Krusche, A.V., Hedges, J.I., Quay, P.D., Richey, J.E., Brown, T.A., 2005. Young organic matter as a source of carbon dioxide outgassing from Amazonian rivers. Nature 436, 538-541.

Patra, S., Liu, C.Q., Li, S.L., Wang, B.L., Wang, Q.L., 2010. A geochemical study on carbon cycling in the Changjiang Estuary. Earth and Environment 38, 409-413.

Pearson, E.J., Juggins, S., Talbot, H.M., Weckström, J., Rosén, P., Ryves, D.B., Roberts S.J., Schmidt, R., 2011. A lacustrine GDGT-temperature calibration from the Scandinavian Arctic to Antarctic: renewed potential for the application of GDGT-paleothermometry in lakes. Geochimica et Cosmochimica Acta 75, 62256238.

Peterse, F., van der Meer, J., Schouten, S., Weijers, J.W., Fierer, N., Jackson, R.B., Kim, J.-H., Sinninghe Damsté, J.S., 2012. Revised calibration of the MBT-CBT paleotemperature proxy based on branched tetraether membrane lipids in surface soils. Geochimica et Cosmochimica Acta 96, 215-229.

Ponton, C., West, A.J., Feakins, S.J., Galy, V., 2014. Leaf wax biomarkers in transit record river catchment composition. Geophysical Research Letters 41, 64206427.

Powers, L., Werne, J.P., Vanderwoude, A.J., Sinninghe Damsté, J.S., Hopmans, E.C., Schouten, S., 2010. Applicability and calibration of the TEX 86 paleothermometer in lakes. Organic Geochemistry 41, 404-413.

Raymond, P.A., Bauer, J.E., 2001. Use of ${ }^{14} \mathrm{C}$ and ${ }^{13} \mathrm{C}$ natural abundances for evaluating riverine, estuarine, and coastal DOC and POC sources and cycling: a review and synthesis. Organic Geochemistry 32, 469-485.

Schouten, S., Hopmans, E.C., Sinninghe Damsté, J.S., 2013. The organic geochemistry of glycerol dialkyl glycerol tetraether lipids: a review. Organic Geochemistry 54, 19-61.

Schouten, S., Huguet, C., Hopmans, E.C., Kienhuis, M.V., Sinninghe Damsté, J.S., 2007 Analytical methodology for $\mathrm{TEX}_{86}$ paleothermometry by high-performance liquid chromatography/atmospheric pressure chemical ionization-mass spectrometry. Analytical Chemistry 79, 2940-2944.

Smil, V., 2007. Global material cycles. In: Culter J.C. (Ed.), Encyclopedia of Earth, http://www.eoearth.org/article/Global_material_cycles.

Still, C.J., Berry, J.A., Collatz, G.J., DeFries, R.S., 2003. Global distribution of $C_{3}$ and $C_{4}$ vegetation: carbon cycle implications. Global Biogeochemical Cycles 17. http:// dx.doi.org/10.1029/2001GB001807.

Tan, F., Edmond, J., 1993. Carbon isotope geochemistry of the Orinoco Basin. Estuarine, Coastal and Shelf Science 36, 541-547.

Tao, S., Eglinton, T.I., Montluçon, D.B., McIntyre, C., Zhao, M., 2015. Pre-aged soil organic carbon as a major component of the Yellow River suspended load: regional significance and global relevance. Earth and Planetary Science Letters $414,77-86$.

Trefethen, J.M., 1950. Classification of sediments. American Journal of Science 248, 55-62.

Walsh, E.M., Ingalls, A.E., Keil, R.G., 2008. Sources and transport of terrestrial organic matter in Vancouver Island fjords and the Vancouver-Washington Margin: a multiproxy approach using $\delta^{13} \mathrm{C}_{\mathrm{org}}$, lignin phenols, and the ether lipid BIT index. Limnology and Oceanography 53, 1054-1063.

Wang, H., Liu, W., Zhang, C.L., Wang, Z., Wang, J., Liu, Z., Dong, H., 2012. Distribution of glycerol dialkyl glycerol tetraethers in surface sediments of Lake Qinghai and surrounding soil. Organic Geochemistry 47, 78-87.

Wang, H., Saito, Y., Zhang, Y., Bi, N., Sun, X., Yang, Z., 2011. Recent changes of sediment flux to the western Pacific Ocean from major rivers in East and Southeast Asia. Earth-Science Reviews 108, 80-100.

Weijers, J.W., Schouten, S., Linden, M., Geel, B., Sinninghe Damsté, J.S., 2004. Water table related variations in the abundance of intact archaeal membrane lipids in a Swedish peat bog. FEMS Microbiology Letters 239, 51-56.

Weijers, J.W., Schouten, S., Spaargaren, O.C., Sinninghe Damsté, J.S., 2006. Occurrence and distribution of tetraether membrane lipids in soils: implications for the use of the $\mathrm{TEX}_{86}$ proxy and the BIT index. Organic Geochemistry 37, 1680-1693.

Weijers, J.W., Schouten, S., van den Donker, J.C., Hopmans, E.C., Sinninghe Damsté J.S., 2007. Environmental controls on bacterial tetraether membrane lipid distribution in soils. Geochimica et Cosmochimica Acta 71, 703-713.

Wu, Y., Zhang, J., Liu, S., Zhang, Z., Yao, Q., Hong, G., Cooper, L., 2007. Sources and distribution of carbon within the Yangtze River system. Estuarine, Coastal and Shelf Science 71, 13-25.

Wu, Q.X., Han, G.L., Tang, Y., 2012. Temporal and spatial variation of water chemistry and dissolved inorganic carbon isotope characterization in Three Gorges Reservoir. Acta Scientiae Circumstantiae 32, 654-661.

Xie, S., Pancost, R.D., Chen, L., Evershed, R.P., Yang, H., Zhang, K., Huang, J., Xu, Y., 2012. Microbial lipid records of highly alkaline deposits and enhanced aridity 
associated with significant uplift of the Tibetan Plateau in the Late Miocene. Geology 40, 291-294.

Xu, K.H., Milliman, J.D., Yang, Z.S., Xu, H., 2007. Climatic and anthropogenic impacts on the water and sediment discharge from the Yangtze River (Changjiang), 1950-2005. In: Gupta, A. (Ed.), Large Rivers: Geomorphology and Management. John Wiley \& Sons, 609, p. 626.

Yang, H., Ding, W., Wang, J., Jin, C., He, G., Qin, Y., Xie, S., 2012. Soil pH impact on microbial tetraether lipids and terrestrial input index (BIT) in China. Science China Earth Sciences 55, 236-245.

Yang, G., Zhang, C.L., Xie, S., Chen, Z., Gao, M., Ge, Z., Yang, Z., 2013. Microbia glycerol dialkyl glycerol tetraethers from river water and soil near the Three Gorges Dam on the Yangtze River. Organic Geochemistry 56, 40-50.

Yang, H., Pancost, R.D., Dang, X., Zhou, X., Evershed, R.P., Xiao, G., Tang, C., Gao, L., Guo, Z., Xie, S., 2014. Correlations between microbial tetraether lipids and environmental variables in Chinese soils: optimizing the paleoreconstructions in semi-arid and arid regions. Geochimica et Cosmochimica Acta $126,49-69$.
Yu, H., Wu, Y., Zhang, J., Yao, Q.Z., Zhu, Z.Y., 2007. The characteristics of lignin of plant and soil samples in the Yangtze River (Changjiang) Drainage Basin. Acta Scientiae Circumstantiae 27, 817-823 (in Chinese with English abstract).

Yu, H., Wu, Y., Zhang, J., Deng, B., Zhu, Z.Y., 2011. Impact of extreme drought and the Three Gorges Dam on transport of particulate terrestrial organic carbon in the Changjiang (Yangtze) River. Journal of Geophysical Research: Earth Surface 2003-2012, 116. http://dx.doi.org/10.1029/2011JF002012.

Zell, C., Kim, J.-H., Moreira-Turcq, P., Abril, G., Hopmans, E.C., Bonnet, M.-P., Sobrinho, R.L., Sinninghe Damsté, J.S., 2013. Disentangling the origins of branched tetraether lipids and crenarchaeol in the lower Amazon River: implications for GDGT-based proxies. Limnology and Oceanography 58, 343-353.

Zhu, S.F, Liu, C.O. Tao, F.X., Wang Z.L., Piao, H.C, 2006. Geochemical characteristics of stable carbon isotopes in soil organic matter from karst areas. Earth and Environment 34, 51-58 (in Chinese with English abstract).

Zhu, C., Weijers, J.W., Wagner, T., Pan, J.-M., Chen, J.-F., Pancost, R.D., 2011. Sources and distributions of tetraether lipids in surface sediments across a large riverdominated continental margin. Organic Geochemistry 42, 376-386. 